\title{
Resumption of follicular activity in the early post-partum period of dairy cows*
}

\author{
J. D. Savio $\Varangle$, M. P. Boland $\ddagger$, N. Hynes $†$ and J. F. Roche $\uparrow$ \\ $\uparrow$ Faculty of Veterinary Medicine, University College Dublin, Ballsbridge, Dublin 4, Ireland; and \\ $\ddagger$ Faculty of Agriculture, University College Dublin, Lyons Estate, Newcastle, Co. Dublin, Ireland
}

\begin{abstract}
Summary. Lactating Friesian dairy cows (2nd-4th parity) which calved in spring $(N=7)$ or autumn $(N=15)$ were used. Their ovaries were examined by ultrasound scanning and blood samples were obtained daily for progesterone and oestradiol concentrations from the 5 th day after calving until the first post-partum ovulation occurred. Five autumn-calving cows selected at random were bled every $15 \mathrm{~min}$ over a 6-h period on 1 day each week for 4 weeks after calving to assess the patterns of LH secretion. Follicular development during the post-partum anoestrous period was characterized by the growth and regression of small $(\leqslant 4 \mathrm{~mm})$ and medium-sized $(5-9 \mathrm{~mm})$ follicles, until a dominant follicle $(>10 \mathrm{~mm}$ ) was detected. The first detected dominant follicle ovulated in 14 cows, became cystic in 4 cows (all in autumn), and failed to ovulate in 1 cow. It was not possible to detect a dominant follicle in 3 cows due to scanning difficulties. The post-partum interval to detection of the first dominant follicle (mean \pm s.d.) was shorter $(P<0.05)$ in autumn $(6.8 \pm 1.8$ days $)$ than in spring (20 $\pm 10 \cdot 1$ days). However, there was no significant difference between the respective intervals to first ovulation (autumn $27.4 \pm 25.9$ and spring $27 \cdot 3 \pm 18.9$ days). Autumncalved cows which had cysts had longer $(P<0.001)$ intervals to first ovulation $(58.2 \pm 23.5$ days) than did normal cows (12.0 \pm 2.5 days). All cows with cysts had twin ovulations at their first post-partum ovulation. A pulsatile pattern of $\mathrm{LH}$ secretion was detected in the first week post-partum and $\mathrm{LH}$ pulse frequency was 2-3 per 6-h period in Weeks 1 and 2 post partum and increased to 5-7 pulses per 6-h period in the presence of a dominant or cystic follicle. Concentrations of progesterone in plasma during post-partum anoestrus were usually low $(<0.2 \mathrm{ng} / \mathrm{ml})$; oestradiol concentrations were also low $(<5 \mathrm{pg} / \mathrm{ml})$, but higher values $(5-110 \mathrm{pg} / \mathrm{ml})$ were observed in cows that had a dominant or a cystic follicle.
\end{abstract}

Keywords: cow; follicle; oestrus; post partum; ultrasound

\section{Introduction}

Early resumption of ovarian activity in post-partum cows is required to achieve calving to first service and conception intervals of 55 and 85 days respectively, which are necessary targets if a 365-day calving interval is to be attained. After regression of the corpus luteum of pregnancy, there is a variable anovulatory period before first ovulation takes place. The length of this anovulatory period can be affected by the level of nutrition, body condition, suckling, lactation, dystocia, breed, age, month of calving, uterine pathology and chronic debilitating disease (Zemjanis, 1961; Roberts, 1971; Kaltenbach, 1980; Lamming et al., 1981; Tucker, 1982; Chauhan et al., 1984). The initiation of follicular growth is not clearly understood in this early post-partum period. Previous reports 
indicated that there was some follicular development before first ovulation. Dufour \& Roy (1985) studied the antral follicular populations in dairy cows at 15,25 and 35 days after calving and reported growth of small antral follicles between Days 15 and 35. Similarly, Spicer et al. (1986) reported that large follicles $(>8 \mathrm{~mm})$ were present by Day 7 post partum and that the number of follicles $4-7.9 \mathrm{~mm}$ in diameter increased between Days 7 and 42 after parturition in acyclic, suckled beef cows.

One of the main reasons why the pattern of development of ovarian follicles in the early postpartum period is not understood is the inability to follow daily changes in growth and regression of individual ovarian follicles accurately. However, the development of ultrasound techniques makes it possible to measure individual follicles and to follow their sequential pattern of development and regression (Pierson \& Ginther, 1988; Savio et al., 1988; Sirois \& Fortune, 1988). The aim of the present work was to determine the patterns of follicular growth in the early post-partum period of dairy cows in spring and autumn, and to relate these patterns to hormone concentrations in blood.

\section{Materials and Methods}

Friesian dairy cows in their 2nd-4th parity were used; 7 had calved between 20 March and 9 April (spring), and 15 between 8 October and 16 November (autumn). The ovaries of all cows were scanned daily from the 5 th day after calving until first ovulation as previously described in detail and validated (Savio et al., 1988), using a linear array ultrasound scanner equipped with a $5 \mathrm{MHz}$ rectal probe (Dynamic Imaging Ltd, Livingstone EH54 9BX, UK). Follicles $\geq 4 \mathrm{~mm}$ were detectable and a dominant follicle was defined as the largest follicle in the ovary of $\geq 10 \mathrm{~mm}$ in diameter in the absence of other large follicles, while a cystic follicle was defined as a dominant follicle that exceeded $25 \mathrm{~mm}$ in diameter for more than 10 days. Concomitantly, with each ultrasound examination, the cows were bled by jugular puncture and the resultant plasma samples were stored at $-20^{\circ} \mathrm{C}$ until they were assayed for progesterone and oestradiol. To study the patterns of LH secretion, 5 autumn-calving cows, selected at random, were bled every 15 min over a 6-h period once per week from the 1 st week post partum until first ovulation occurred. Blood was collected through an indwelling jugular catheter. Serum was obtained by centrifugation following storage at room temperature for $1 \mathrm{~h}$ and at $5^{\circ} \mathrm{C}$ for $12 \mathrm{~h}$ and was stored at $-20^{\circ} \mathrm{C}$ until assayed. The criterion for determining an LH pulse was similar to that of Walters et al. (1984) who defined a pulse as occurring when the value of the highest sample (peak) exceeded a preceding sample (basal) by at least 4 times the coefficient of variation of the assay. There had to be one more value on the decreasing slope to satisfy the requirements for a pulse.

Progesterone concentrations were determined in plasma samples by the radioimmunoassay method described by Dieleman \& Schoenmakers (1979). The intra- and interassay coefficients of variation were $11 \%$ and $4 \%$, respectively. The sensitivity of the assay was $0.1 \mathrm{ng} / \mathrm{ml}$. Oestradiol values were analysed by the method described in detail by O'Callaghan (1985), which is a modification of the radioimmunoassay method previously reported by England $e$ al. (1974). The intra- and interassay coefficients of variation were $14.2 \%$ and $1.2 \%$, respectively. The sensitivity of the assay varied between 2 and $3 \mathrm{pg} / \mathrm{ml}$. LH was assayed by the method of Niswender et al. (1969), as subsequently modified by Ronayne et al. (1989). The intra- and interassay coefficients of variation were $2.7 \%$ and $0.8 \%$, respectively. The sensitivity of the assay was $0.5 \mathrm{ng} / \mathrm{ml}$.

The autumn-calving cows were housed, milked twice daily and given grass silage ad libitum and $7 \mathrm{~kg}$ of a balanced concentrate ration. The spring-calving cows were milked twice daily and were turned out to pasture at the end of April. Detection for oestrus was carried out twice daily by visual observations. The progesterone and oestradiol concentrations were used to describe the endocrine status of the cows and hence they were not statistically analysed. The follicular data were statistically analysed as previously described by Savio et al. (1988).

\section{Results}

\section{Follicular development during the early post-partum period}

The ultrasound examination during the early post-partum period (Days 5-15) was usually difficult due to the anatomy of the involuting uterus. In 3 cows which ovulated before Day 10 post partum, it was especially difficult and the first post-partum dominant follicle was not accurately identified. In the remaining cows, ovarian follicular development during the early post-partum period was characterized by the growth and regression of follicles smaller than $8 \mathrm{~mm}$ in diameter until the detection of the first post-partum dominant follicle. The number of small follicles usually varied between 2 and 5 per day, although they were not accurately identified during successive days. 
The first dominant follicle ovulated in 14 out of 19 cows (Fig. 1), became cystic in 4 out of 19 cows, while one cow (No. 133) had two periods of growth and regression of a dominant follicle before the development of the ovulatory dominant follicle (Fig. 2). The accurate identification and monitoring of small and medium-sized individual follicles was difficult in the early post-partum period before development of the first dominant follicle.

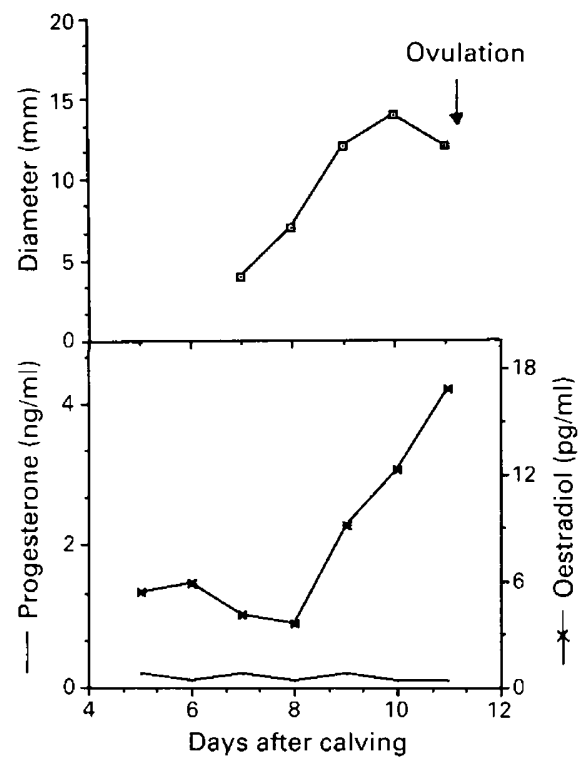

Fig. 1. The development and ovulation of the first dominant follicle in conjunction with progesterone and oestradiol concentrations in blood of Cow 112 during the early post-partum period.

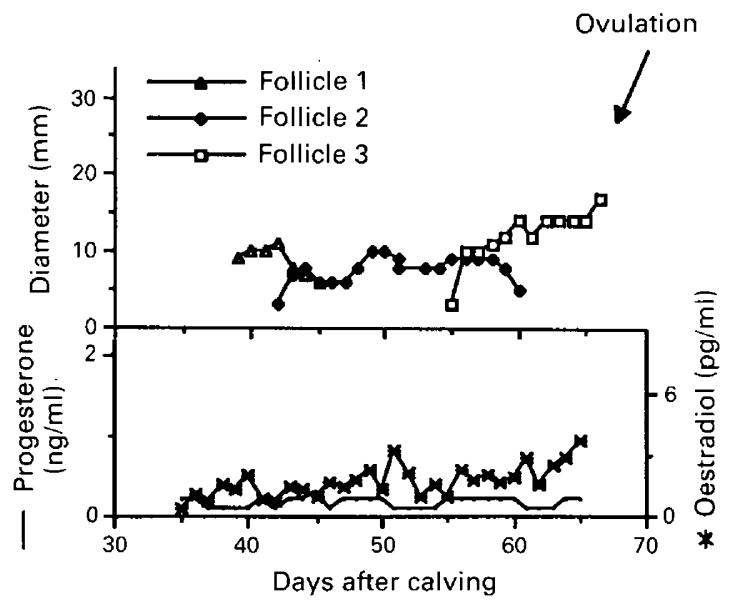

Fig. 2. The growth pattern of 2 dominant follicles before ovulation of the 3 rd dominant follicle in conjunction with progesterone and oestradiol concentrations in blood of Cow 133 during the early post-partum period. 


\section{Occurrence of cystic follicles}

In 4 of 15 autumn-calving cows the first dominant follicle, detected between Days 5 and 8 after calving, became cystic. These follicles, when they occurred as single cysts, were large and spherical and grew to $40-45 \mathrm{~mm}$ in diameter (Figs $3 \& 4$ ). When more than one cyst was present in the same ovary, the normal spherical shape was modified at the points of contact. The walls of the cysts were less clearly demarcated than the walls of normal follicles, and variable amounts of intrafollicular echogenic material were frequently detected. In cow No. 124 (Fig. 3) the echogenic intrafollicular material observed appeared to have luteal-like characteristics, and its appearance coincided with the elevated progesterone concentrations detected on Days 33 to 38 post partum. With the exception of this rise in cow No. 124, plasma concentrations of progesterone in cows with cystic follicles were consistently between 0.1 and $0.3 \mathrm{ng} / \mathrm{ml}$ from calving to the development of the first corpus luteum (CL).

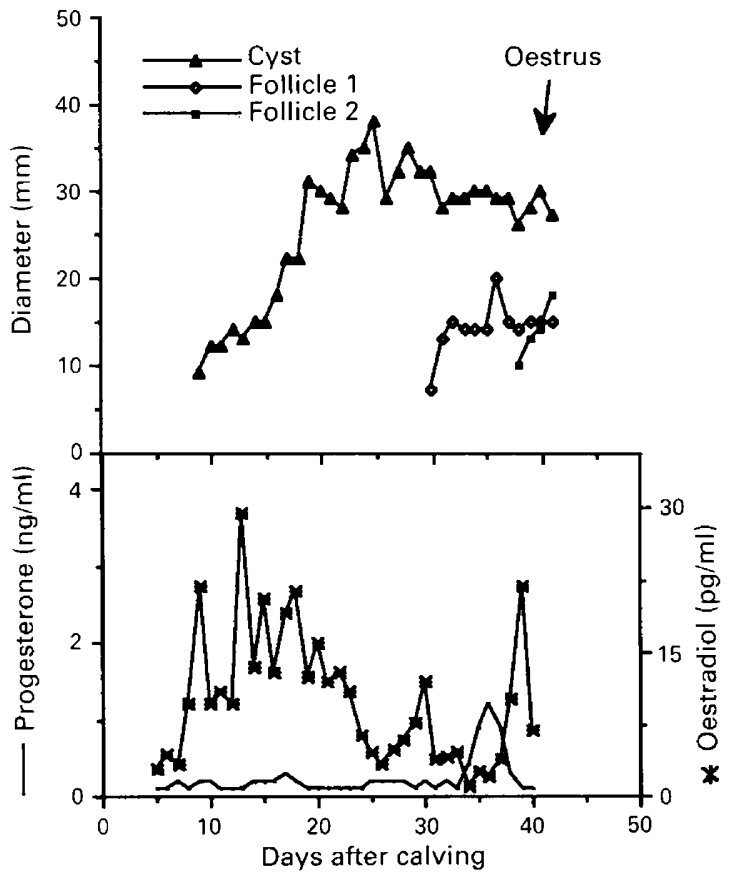

Fig. 3. The initial development of a dominant follicle which became cystic and the subsequent development of 2 dominant follicles which ovulated simultaneously in conjunction with progesterone and oestradiol concentrations in blood of Cow 124 during the early post-partum period.

Two cows, No. 124 (Fig. 3) and No. 183 had single cysts; Cow 243 had 2 consecutive cystic periods (Fig. 4), and Cow 114 had at least 3 simultaneous cysts detected in the right ovary (Fig. 5). Sexual behaviour among the cows with cystic ovaries was also different; Cows 124 and 183 did not express oestrous behaviour during the cystic period. Cow 243 was always interacting with cows that were in oestrus, and her own oestrous symptoms were intense at the time of development of the second cyst. Cow 114 showed regular intense oestrous symptoms manifested through increased attempts to seek out other oestrous cows, mounting activity and standing oestrous behaviour that became more obvious during the development of each new cyst. At first ovulation, all cows with ovarian cysts had twin ovulations. In 3 cows (Nos 114, 124 and 183) both preovulatory follicles 


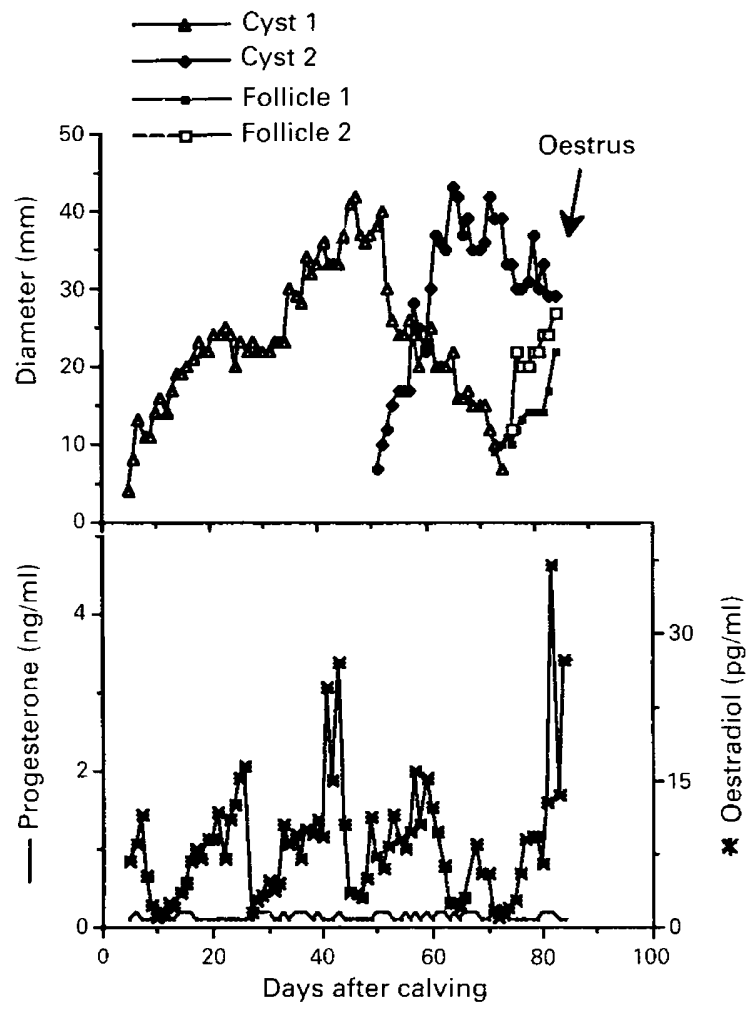

Fig. 4. The development of 2 consecutive cystic follicles and the subsequent development of 2 dominant follicles which ovulated simultaneously in conjunction with progesterone and oestradiol concentrations in blood of Cow 243 during the early post-partum period.

were located in the ovary opposite that previously bearing the cyst; the remaining cow (No. 243) had 1 ovulation in each ovary.

\section{Post-partum intervals to development of the first dominant follicle and first ovulation}

The mean ( \pm s.d.) post-partum interval to detection of the first dominant follicle (Fig. 6 ) for all cows in which it was possible to detect it (19 cows) was 11.6 \pm 8.9 days (range 5-39) and to first ovulation (including the cows that developed cysts) was $27.4 \pm 23.0$ days (range 9-85 days). The post-partum interval to detection of the first dominant follicle was significantly shorter $(P<0 \cdot 05)$ in autumn-calving cows $(6.8 \pm 1.8$ days, $N=12)$ than in spring-calving cows $(20 \pm 10 \cdot 1$ days, $\mathrm{N}=7$ ). In the autumn-calving cows, there was no difference in the post-partum interval to the detection of the first dominant follicle in cows in which the first dominant follicle ovulated (normal cows) and in those in which it became cystic (Table 1). In relation to the post-partum interval to first ovulation, there was no difference between cows that calved in spring or autumn $(27 \cdot 3 \pm 18 \cdot 9$ and $27.4 \pm 25.9$ days, respectively); but when the autumn-calved cows were separated, based on the type of follicle they had developed (normal or cystic), cows which had developed cysts had significantly $(P<0.001)$ longer post-partum intervals to first ovulation $(58.2 \pm 23.5$ days $)$ than did normal cows (12.0 \pm 2.5 days) (Table 1$)$. When only cows with normal dominant follicles were considered, the cows that calved in autumn tended to have shorter and less variable intervals $(P<0 \cdot 10)$ from calving to first ovulation than did cows that calved in spring $(12 \cdot 0 \pm 2 \cdot 5, \mathrm{~N}=8$, vs $27 \cdot 3 \pm 18.9$ days, $N=7$, respectively). In the majority $(94 \%)$ of normal cows, the first ovulation occurred without signs of oestrus being detected. 


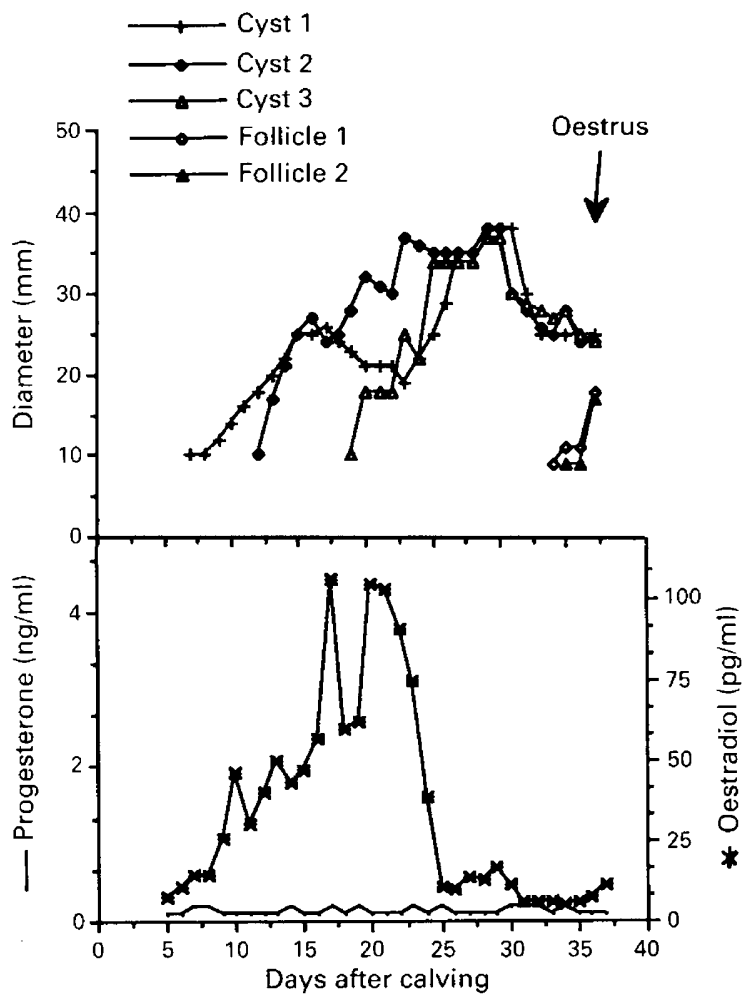

Fig. 5. The development of 3 dominant follicles which became cystic and the subsequent development of 2 dominant follicles which ovulated simultaneously in conjunction with progesterone and oestradiol concentrations in blood of Cow 114 during the early post-partum period.

Table 1. The interval from calving to the detection of the first dominant follicle and first ovulation in cows which calved in autumn, according to whether the first dominant follicle ovulated or became cystic

\begin{tabular}{lccc}
\hline & \multicolumn{3}{c}{ Post-partum interval to: } \\
\cline { 3 - 4 } Status & $\begin{array}{c}\text { No. of } \\
\text { cows }\end{array}$ & $\begin{array}{c}\text { First } \\
\text { dominant } \\
\text { follicle }\end{array}$ & $\begin{array}{c}\text { First } \\
\text { ovulation }\end{array}$ \\
\hline Normal & 8 & $6 \cdot 8 \pm 2 \cdot 0^{\mathrm{a}}$ & $12 \cdot 0 \pm 2 \cdot 5^{\mathrm{b}}$ \\
Cystic & 4 & $7 \cdot 0 \pm 1 \cdot 4^{\mathrm{a}}$ & $58 \cdot 2 \pm 23 \cdot 5^{\mathrm{c}}$ \\
\hline
\end{tabular}

Values are mean \pm s.d.

Means in columns with different superscripts are significantly different $(P<0 \cdot 001)$.

\section{Episodic LH secretion during the post-partum period}

The weekly patterns of LH secretion, in some individual animals, during the period from calving to first post-partum ovulation, are shown in Fig. 7. In all cows, variable amplitude and/or 
frequency patterns of pulsatile LH secretion were identified in every sampling period. For each 6-h sampling period, there were generally $2-3 \mathrm{LH}$ pulses when concentrations of oestradiol were low $(<5 \mathrm{pg} / \mathrm{ml})$; this increased to about 6 pulses when oestradiol concentrations increased $(>10 \mathrm{pg} / \mathrm{ml})$, coinciding with the development of either a dominant follicle or an ovarian cyst. An exception was Cow 183 (Fig. 7), which did not show increased frequency of LH pulse secretion, in parallel with the high concentrations of oestradiol detected on Day 10 after calving. During periods of low frequency LH pulses ( $2-3$ pulses $/ 6 \mathrm{~h}$ ) the amplitude varied between 3 and $5 \mathrm{ng} / \mathrm{ml}$, but, in contrast, when LH pulsatile frequency increased $(>3$ pulses $/ 6 \mathrm{~h}$ ) basal levels also increased, and the amplitude decreased to $2-3 \mathrm{ng} / \mathrm{ml}$.
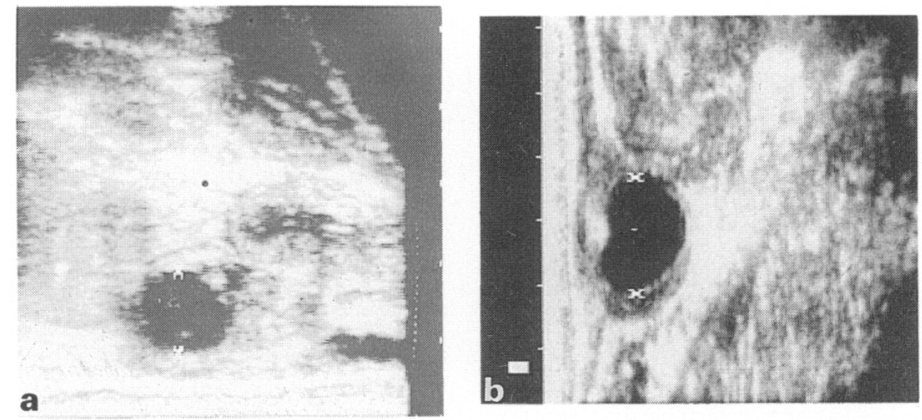

Fig. 6. Dominant follicles of (a) $11 \mathrm{~mm}$ and (b) $18 \mathrm{~mm}$ diameter detected in post-partum dairy cows.

\section{Concentrations of progesterone and oestradiol}

Progesterone concentrations were low during the post-partum anoestrous period, with the exception of Cow 124, in which progesterone was elevated before first ovulation occurred (Fig. 3). Oestradiol concentrations in normal cows were below the sensitivity of the assay throughout the anoestrous period until the development of a dominant follicle. Cows that developed cysts showed prolonged periods of high concentrations of oestradiol in conjunction with the development of the cysts (Figs 3, 4 \& 5). In these cows the high concentrations of oestradiol, presumably from the cysts, returned to basal level 10-15 days before first ovulation, despite the fact that morphologically the cysts were still detectable by ultrasound examination. The highest concentrations of oestradiol recorded in the present study $(>110 \mathrm{pg} / \mathrm{ml})$ were detected in Cow 114 , coinciding with the period of detection of 3 large cysts (Fig. 5).

\section{Discussion}

In the present study, the identification of the first post-partum dominant follicle in cows that did not develop cysts asually occurred 3-5 days before first ovulation. This marked the end of a period of follicular growth characterized by the development of mainly small but a few medium sized follicles. The absence of large follicles, which was a consistent finding in this study, in cows with anoestrous periods long enough to allow accurate sequential daily ultrasound examinations (e.g. $>20$ days), is in agreement with the data of Dufour \& Roy (1985) who reported that the follicular population during early post partum in dairy cows consisted predominantly of follicles $<4 \mathrm{~mm}$ in diameter. Peter \& Bosu (1988) also measured the size of the largest follicle by ultrasound examinations during successive days of the post-partum period in Holstein cows and, in spite of the difficulties of doing routine examinations early after calving, the size of the largest follicle present never 


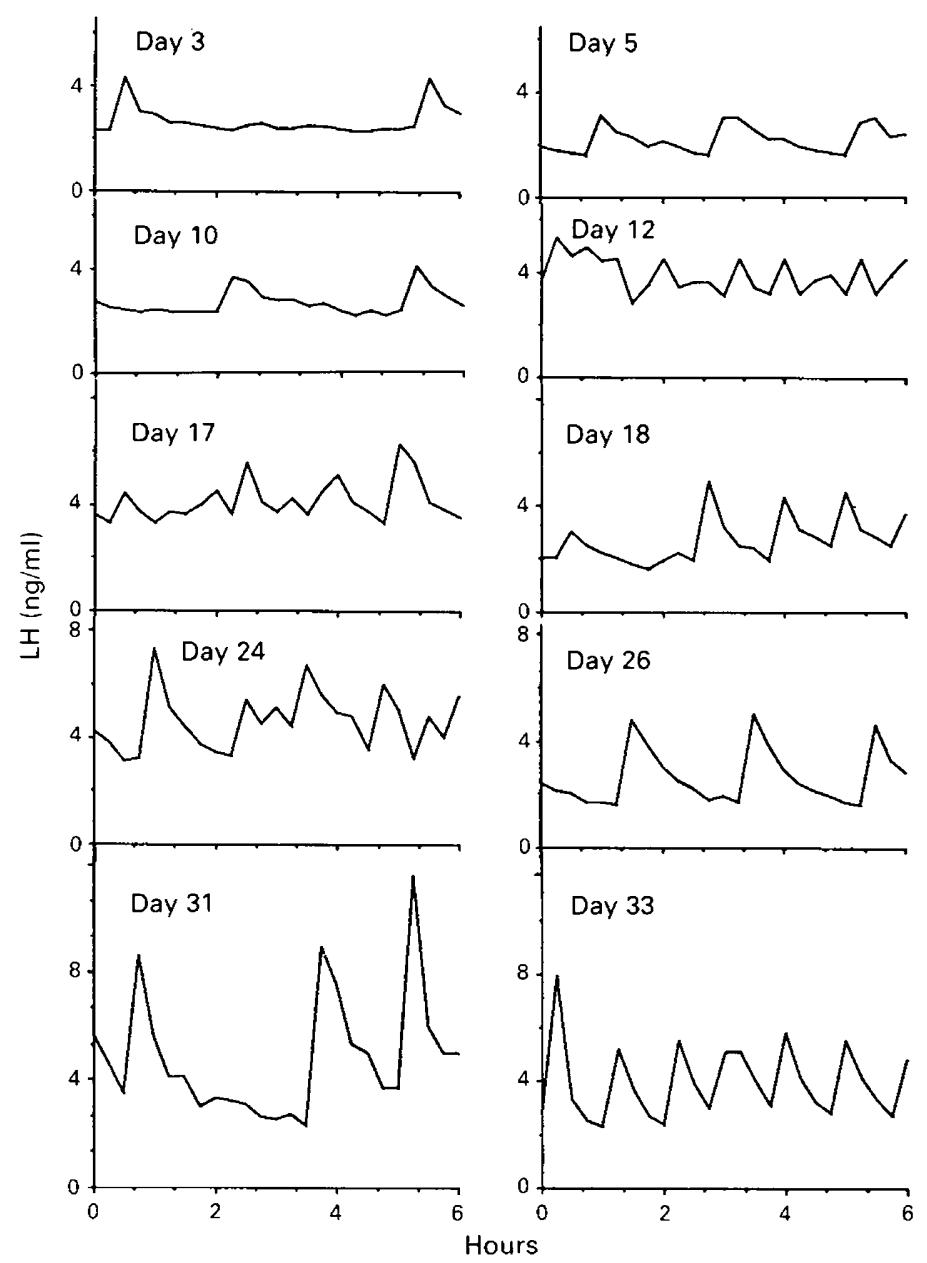

Fig. 7. LH concentrations in dairy cows during 6-h periods at various times post partum (cow 183, left; cow 114, right).

exceeded $9 \mathrm{~mm}$. The early return to active follicular development in all cows, and the fact that some cows ovulated before Day 10 after calving, demonstrated the ability of the ovary to resume activity early after calving. It suggests that ovarian responsiveness may not be the major reason for the variable duration of the post-partum anoestrous periods commonly observed in cattle (Peters, 1984).

The seasonal effect on follicular development observed in this study is in agreement with the data of Bulman \& Lamming (1978) who found an earlier resumption of cyclicity, based on progesterone analysis, in autumn-calving cows compared to spring calvers. These results and those of Hansen et al. (1983), Critser et al. (1983, 1987), McNatty et al. (1984) and Stanisiewski et al. (1988) strongly support the hypothesis of occurrence of seasonality in cattle, which although less marked than in sheep, can modulate some reproductive patterns. In agreement with the hypothesis of seasonality and with previous reports of higher incidence of cystic ovaries during winter months (Roberts, 1955), all the cysts observed in the early post-partum period in the present study were found in the ovaries of cows calved during autumn.

Although the aetiology is not clearly established, all the follicles that became cystic were detected between Days 5 and 8 post partum, and though in some other cows dominant follicles 
detected at the same stage ovulated, they developed in a physiological stage characterized by low pituitary responsiveness to GnRH (Webb et al., 1977; Fernandes et al., 1978; Mawhinney et al., 1979) and low biological activity of the LH secreted (Weesner et al., 1987). These findings support the hypothesis of a possible insufficiency of $\mathrm{LH}$ at the time of ovulation as a cause of the formation of cysts (Erb et al., 1973; Nadaraja \& Hansel, 1976; Kesler \& Garverick, 1982). Although the cows that developed ovarian cysts resumed cyclicity spontaneously, the development of cysts significantly delayed the first post-partum ovulation and undoubtedly justifies the inclusion of cystic ovaries as a cause of poor reproductive performance in cows (Roberts, 1971; Kesler \& Garverick, 1982; Chauhan et al., 1984; Ijaz et al., 1987). On the other hand, the absence of a clear differential behavioural pattern in cows that had ovarian cysts and the fact that plasma concentrations of progesterone were generally low mean that the diagnosis of cysts really requires ovarian examinations. Morrow et al. (1966), Kesler et al. (1979) and Kesler \& Garverick (1982) also considered that the real incidence of ovarian cysts in cattle could be higher than the previously reported rates $(0-20 \%)$ which were based mainly on animals that either showed symptoms or were treated following diagnosis.

In relation to the patterns of $\mathrm{LH}$ secretion, the detection of pulsatile $\mathrm{LH}$ release during the first week post partum in the present study is in agreement with data of Schallenberger \& Prokopp (1985). However, the apparently lower magnitude of the individual peaks during the first 2 weeks post partum probably reflects the reduced availability of releasable LH during the early postpartum period in cattle (Nett, 1987). In addition, the absence of a distinct episodic secretion in response to the coincident high concentrations of oestradiol in Cow 183, on Day 10 after calving, agrees with data of Schallenberger \& Prokopp (1985), who reported a variable period of refractoriness to the stimulatory effects of oestradiol-17 $\beta$ on LH secretion during the early post-partum period in dairy cows. This observation also tends to support the data of Schams et al. (1978), who reported several post-partum ovulations without detection of LH surges in early post-partum dairy cows. Schams et al. (1978) used a 6-h interval for blood sampling, which consistently allowed them to detect the preovulatory LH surges and, therefore, eliminates low frequency of blood sampling as a possible cause of the absence of $\mathrm{LH}$ surges. The variation in the patterns of $\mathrm{LH}$ secretion in coincidence with variable concentrations of oestradiol is in agreement with Karsch (1984), who proposed that ovarian steroids play an important role in regulation of the hypothalamic pulse generator and, consequently, the patterns of gonadotrophin secretion.

Although the number of observations in the present study is not large enough to permit definitive conclusions about the rate of double ovulations, the results showed trends that may help to explain data from previous related studies in cattle. In fact, since the development of ovarian cysts was associated with the majority of the double ovulations observed in the present study (only 1 other double ovulation was registered, and this was in a normal cyclic cow), these data would tend to support the association of twinning with ovarian disturbances in cattle (Erb et al., 1959). In effect, the abnormally long periods of high concentrations of oestradiol, detected in the cows that developed ovarian cysts, suggest a possible alteration of the normal patterns of gonadotrophin secretion due to the positive feedback effect of oestradiol on LH secretion (Kesner et al., 1981). Although the effects of $\mathrm{LH}$ alone in the determination of ovulation rate are not known, a replacement regimen of LH pulses in hamsters hypophysectomized at the post-ovulatory FSH rise is able to induce the development of preovulatory follicles (Goodwin \& Terranova, 1985), and pulsatile LH administration increases ovulation rate in intact hamsters and guinea-pigs (Garza et al., 1984). Elevated LH concentrations occur during the luteal phase in prolific sheep in comparison to breeds with lower ovulation rates (Land et al., 1973; Findlay et al., 1976; Cahill et al., 1981; McNatty et al., 1987).

We thank Mr Michael Hegarty for help during ultrasound examinations; the staff at Lyons Estate for care and bleeding of the animals; Mrs Maria R. Mattiacci for help in analysing the data; Mr Gerard Claffey for the hormone assays; and Miss Miriam Phelan for secretarial assistance. 


\section{References}

Bulman, D.C. \& Lamming, G.E. (1978) Milk progesterone levels in relation to conception, repeat breeding and factors influencing acyclicity in dairy cows. $J$. Reprod. Fert. 54, 447-458.

Cahill, L.P., Saumande, J., Ravault, J.P., Blanc, M., Thimonier, J., Mariana, J.C. \& Mauleon, P. (1981) Hormonal and follicular relationship in ewes of high and low ovulation rates. $J$. Reprod. Fert. 62, 141-150.

Chauhan, F.S., Mgongo, F.O.K. \& Kessy, B.M. (1984) Recent advances in hormonal therapy of bovine reproductive disorders: a review. Vet. Bull. 54, 991-1009.

Critser, J.K., Miller, K.F., Gunsett, F.C. \& Ginther, O.J. (1983) Seasonal LH profile in ovariectomized cattle. Theriogenology 19, 181-191.

Critser, J.K., Block, T.M., Folkman, S. \& Hauser, E.R. (1987) Effect of photoperiod on LH, FSH, prolactin and melatonin patterns in ovariectomized prepubertal heifers. J. Reprod. Fert. 81, 29-39.

Dieleman, S.J. \& Schoenmakers, H.J.N. (1979) Radioimmunoassays to determine the presence of progesterone and estrone in the starfish Asterias rubens. Gen. comp. Endocrinol. 39, $534-542$.

Dufour, J.J. \& Roy, G.L. (1985) Distribution of ovarian follicular populations in the dairy cow within 35 days after parturition. J. Reprod. Fert. 73, 229-235.

England, B., Niswender, G.D. \& Midgley, A.R., Jr (1974) Radioimmunoassay of oestradiol-17 beta without chromatography. J. clin. Endocr. Metab. 38, 42-50.

Erb, R.E., Hinze, P.M. \& Gildow, E.M. (1959) Factors influencing prolificacy of cattle. II. Some evidence that certain reproductive traits are additively inherited. Tech. Bull. Wash. Agric. Exp. Stn, No. 30, $18 \mathrm{pp}$.

Erb, R.E., Monk, E.L., Callahan, C.J. \& Mollet, T.A. (1973) Endocrinology of induced ovarian follicular cysts. J. Anim. Sci. 37, 310, abstr.

Fernandes, L.C., Thatcher, W.W., Wilcox, C.J. \& Call, E.P. (1978) LH release in response to GnRH during the post-partum period of dairy cows. J. Anim. Sci. 46, 443-448.

Findlay, J.K., Cumming, I.A. \& Fairnie, I.J. (1976) The effect of an analogue of LH-RH (D-Ser (TBU)6EA 10; Hoe 766, Hoechst) on gonadotropin secretion, oestrus and ovulation rate in sheep. Theriogenology 6, 620, abstr.

Garza, F., Shaban, M.A. \& Terranova, P.F. (1984) Luteinizing hormone increases the number of ova shed in the cyclic hamster and guinea-pig. $J$. Endocr. 101, 289-298.

Goodwin, J.A. \& Terranova, P.F. (1985) Relationship between LH dependency of preantral follicles and the secondary FSH surge: effects of hypophysectomy and correlations with hCG and FSH binding and follicular steroids. In Proceedings of the Fifth Ovarian Workshop, pp. 243-247. Eds D. O. Toft \& R. J. Ryan. Champaign, Illinois.

Hansen, P.J., Kamwanja, L.A. \& Hauser, E.R. (1983) Photoperiod influences age at puberty of heifers. $J$. Anim. Sci. 57, 985-992.

Ijaz, A., Fahning, M.L. \& Zemjanis, R. (1987) Treatment and control of cystic ovarian disease in dairy cattle: a review. Br. vet. J. 142, 226-237.
Kaltenbach, C.C. (1980) Initiation of puberty and postpartum estrus in beef cattle. In Current Therapy in Theriogenology, pp. 164-168. Ed. D. A. Morrow. W.B. Saunders Company, Philadelphia.

Karsch, F.J. (1984) The hypothalamus and anterior pituitary gland. In Reproduction in Mammals, 2nd edn, vol. 3: Hormonal Control of Reproduction, pp. 1-20. Eds C. R. Austin \& R. V. Short. Cambridge University Press.

Kesler, D.J. \& Garverick, H.A. (1982) Ovarian cysts in dairy cattle: a review. J. Anim. Sci. 55, 1147-1159.

Kesler, D.J., Garverick, H.A., Bierschwal, C.J., Elmore, R.G. \& Youngquist, R.S. (1979) Reproductive hormones associated with normal and abnormal changes in ovarian follicles in postpartum dairy cows. $J$. Dairy Sci. 62, 1290-1296.

Kesner, J.S., Convey, E.M. \& Anderson, C.R. (1981) Evidence that estradiol induces the preovulatory LH surge in cattle by increasing pituitary sensitivity to LHRH and then increasing LHRH release. Endocrinology 108, 1386-1391.

Lamming, G.E., Wathes, D.C. \& Peters, A.R. (1981) Endocrine patterns of the post-partum cow. $J$. Reprod. Fert., Suppl. 30, 155-170.

Land, R.B., Pelletier, J., Thimonier, J. \& Mauleon, P. (1973) A quantitative study of genetic differences in the incidence of oestrus, ovulation and plasma luteinizing hormone concentration in sheep. $J$. Endocr. 58, 305-317.

Mawhinney, S., Roche, J.F. \& Gosling, J.P. (1979) The effects of oestradiol benzoate (OB) and gonadotrophin releasing hormone $(\mathrm{GnRH})$ on reproductive activity in beef cows at different intervals postpartum. Annls Biol. anim. Biochim. Biophys. 19, 1575-1587.

MeNatty, K.P., Hudson, N., Gibb, M., Henderson, K.M., Lun, S., Heath, D. \& Montgomery, G.W. (1984) Seasonal differences in ovarian activity in cows. $J$. Endocr. 102, 189-198.

MeNatty, K.P., Hudson, N., Henderson, K.M., Gibb, M., Morrison, L., Ball, K. \& Smith, P. (1987) Differences in gonadotrophin concentrations and pituitary responsiveness to $\mathrm{GnRH}$ between Booroola ewes which were homozygous (FF), heterozygous $(\mathrm{F}+)$ and non-carriers $(++)$ of a major gene influencing their ovulation rate. J. Reprod. Fert. 80, 577-588.

Morrow, D.A., Roberts, S.J., McEntee, K. \& Gray, H.G. (1966) Postpartum ovarian activity and uterine involution in dairy cattle. J. Am. vet. med. Assoc. 149, 1596-1609.

Nadaraja, R., \& Hansel, W. (1976) Hormonal changes associated with experimentally produced cystic ovaries in the cow. J. Reprod. Fert. 47, 203-208.

Nett, T.M. (1987) Function of the hypothalamichypophysial axis during the post-partum period in ewes and cows. J. Reprod. Fert., Suppl. 34, 201-213.

Niswender, G.D., Reichert, L.E., Jr, Midgley, A.R., Jr \& Nalbandov, A.V. (1969) Radioimmunoassay for bovine and ovine luteinizing hormone. Endocrinology 84, 1166-1173.

O'Callaghan, D. (1985) The effect of exogenous steroid hormones on growth and sexual development in cattle. 
M. Anim. Sci. thesis, pp. 70-78. The National University of Ireland, Dublin.

Peter, A.T. \& Bosu, T.K. (1988) Influence of intrauterine infections and follicular development on the response to $\mathrm{GnRH}$ administration in postpartum dairy cows. Theriogenology 29, 1163-1175.

Peters, A.R. (1984) Reproductive activity of the cow in the post-partum period. I. Factors affecting the length of the post-partum acyclic period. Br. vet. $J$. $140,76-84$.

Pierson, R.A. \& Ginther, O.J. (1988) Ultrasonic imaging of the ovaries and uterus in cattle. Theriogenology 29, 31-37.

Roberts, S.J. (1955) Clinical observations on cystic ovaries in dairy cattle. Cornell Vet. 45, 497-513.

Roberts, S.J. (1971) Veterinary Obstetrics and Genital Diseases, 2nd edn. S. J. Roberts, Ithaca.

Ronayne, E., Jordan, B., Quirke, J.F. \& Roche, J.F. (1989) The effect of frequency of administration of melatonin on the time of onset of the breeding season in anoestrous ewes. Anim. Reprod. Sci. 18, 13-24.

Savio, J.D., Keenan, L., Boland, M.P. \& Roche, J.F. (1988) Pattern of growth of dominant follicles during the oestrous cycle of heifers. J. Reprod. Fert. 83, $663-671$.

Schallenberger, E. \& Prokopp, S. (1985) Gonadotrophins and ovarian steroids in cattle. IV. Re-establishment of the stimulatory feed-back action of oestradiol-17 beta on LH and FSH. Acta endocrin., Copenh. 109, $44-49$.

Schams, D., Schallenberger, E., Menzer, C.H., Stangl, J., Zottmeier, K., Hoffmann, B. \& Karg, H. (1978) Profiles of $\mathrm{LH}, \mathrm{FSH}$ and progesterone in post-partum dairy cows and their relationship to the commencement of cycling functions. Theriogenology 10, 453-468.
Sirois, J. \& Fortune, J.E. (1988) Ovarian follicular dynamics during the estrous cycle in heifers monitored by real-time ultrasonography. Biol. Reprod. 39, 308-317.

Spicer, L.J., Leung, K., Convey, E.M., Gunther, J., Short, R.E. \& Tucker, H.A. (1986) Anovulation in postpartum suckled beef cows. 1. Associations among size and numbers of ovarian follicles, uterine involution and hormones in serum and follicular fluid. J. Anim. Sci. 62, 734-741.

Stanisiewski, E.P., Chapin, L.T., Ames, N.K., Zinn, S.A. \& Tucker, H.A. (1988) Melatonin and prolactin concentrations in blood of cattle exposed to 8,16 or 24 hours of daily light. J. Anim. Sci. 66, 727-734.

Tucker, H.A. (1982) Seasonality in cattle. Theriogenology 17, 53-59.

Walters, D.L., Schams, D. \& Schallenberger, E. (1984) Pulsatile secretion of gonadotrophins, ovarian steroids and ovarian oxytocin during the luteal phase of the oestrous cycle in the cow. J. Reprod. Fert. 71, 479-491.

Webb, R., Lamming, G.E., Haynes, N.B., Hafs, H.D. \& Manns, J.G. (1977) Response of cyclic and postpartum suckled cows to injections of synthetic LHRH. J. Reprod. Fert. 50, 203-210.

Weesner, G.D., Norris, T.A., Forrest, D.W. \& Harms, P.G (1987) Biological activity of luteinizing hormone in the peripartum cow: least activity at parturition with an increase throughout the postpartum interval. Biol. Reprod. 37, 851-858.

Zemjanis, R. (1961) Incidence of anestrus in dairy cattle. J. Am. vet. med. Ass. 139, 1203-1207.

Received 26 June 1989 